\title{
ANTIMICROBIAL ACTIVITY OF SURFACTANTS PRODUCED BY BACILLUS SUBTILIS R14 AGAINST MULTIDRUG-RESISTANT BACTERIA
}

\author{
Paulo André Vicente Fernandes ${ }^{1}$; Isabel Renata de Arruda²; Antônio Fernando Amatto Botelho dos Santos ${ }^{3}$; \\ Ana Albertina de Araújo ${ }^{4}$; Ana Maria Souto Maior5; Eulália Azevedo Ximenes ${ }^{6 *}$
}

\begin{abstract}
${ }^{1}$ Universidade Federal de Pernambuco, Recife, PE, Brasil; ${ }^{2}$ Departamento de Antibióticos, Universidade Federal de Pernambuco, Recife, PE, Brasil; ${ }^{3}$ Laboratório de Bacteriologia Clínica do Hospital Oswaldo Cruz, Recife, PE, Brasil; ${ }^{4}$ Laboratório de Central da Prefeitura da Cidade do Recife, Recife, PE, Brasil; ${ }^{5}$ Laboratório de Processos Biotecnológicos, Universidade Federal de Pernambuco, Recife, PE, Brasil; ${ }^{6}$ Laboratório de Bioquímica e Fisiologia de Microrganismos, Universidade Federal de Pernambuco, Recife, PE, Brasil.
\end{abstract}

Submitted: November 29, 2006; Returned to authors for corrections: February 08, 2007; Approved: August 30, 2007.

\begin{abstract}
Lipopeptides represent a class of microbial surfactants with increasing scientific, therapeutic and biotechnological interests. The genus Bacillus is a producer of these active compounds, and among them B. subtilis produces surfactin, the most potent biosurfactant known. These compounds can act as antibiotics, antivirals, antitumorals, immunomodulators and enzyme inhibitors. In this work, the antimicrobial activity of biosurfactants obtained by cultivation of $B$. subtilis R14 was investigated against multidrug-resistant bacteria. During cultivation in defined medium, the surface tension of the medium was reduced from $54 \mathrm{mN} / \mathrm{m}$ in the beginning of the microbial growth to $30 \mathrm{mN} / \mathrm{m}$ after 20 hours. A crude surfactant concentration of $2.0 \mathrm{~g} / \mathrm{L}$ was obtained after 40 hours of cultivation. A preliminary characterization suggested that two surfactants were produced. The evaluation of the antimicrobial activity of these compounds was carried out against 29 bacteria. Enterococcus faecalis (11 strains), Staphylococcus aureus (6 strains) and Pseudomonas aeruginosa (7 strains) and Escherichia coli CI 18 (1 strain) displayed a profile of well defined drug resistance. All strains were sensitive to the surfactants, in particular Enterococcus faecalis. The results demonstrated that lipopeptides have a broad spectrum of action, including antimicrobial activity against microorganisms with multidrug-resistant profiles.
\end{abstract}

Key words: Biosurfactant, Bacillus subtilis, Lipopeptides, Antimicrobial activity

\section{INTRODUCTION}

Surfactants are amphipathic molecules consisting of both hydrophilic and hydrophobic moieties. Partition occurs preferentially at the interface between fluid phases with different degrees of polarity (3). The surface and interfacial tension reducing properties of surfactants present excellent detergency and emulsifying, foaming and dispersing traits, making them some of the most versatile products for use in chemical processes (10).

Microbial compounds which exhibit pronounced surface activity are classified as biosurfactants. Microbial biosurfactants include a wide variety of surface active compounds, such as glycolipids, lipopeptides, polysaccharide-protein complexes, phospholipids, fatty acids, and neutral lipids (15). Biosurfactants commonly have the advantages of biodegradability, low toxicity, and biocompatibility over chemically synthesized surfactants (18). In particular, the most suitable agent for a selected application may be adapted by the choice of the producer organism, the composition of the nutrient broth, and the culture conditions (23).

Among the genus Bacillus, B. subtilis produces a broad spectrum of bioactive lipopeptides which have a great potential

*Corresponding Author. Mailing address: Laboratório de Bioquímica e Fisiologia de Microrganismos, Centro de Ciências Biológicas, Departamento de Antibióticos, UFPE. Rua Artur de Sá, S/N, Cidade Universitária, 50670-901, Recife, PE, Brasil. Tel.: (81) 2126-8346 R: 213 ou (81) $2126-8346$. E-mail: eulaliaximenes@yahoo.com.br 
for biotechnological and biopharmaceutical applications. The characteristic structure of lipopeptides is a fatty acid combined with an amino-acid moiety. Several lipopeptides have potent antibiotic activity and have been the subject of several studies on the discovery of new antibiotics. The list includes surfactin, produced by $B$. subtilis, the most powerful biosurfactant known to date (17). These compounds have many pharmacological activities: antibacterial, antifungal, antiviral, and antimycoplasma properties; inhibition of the fibrin clot formation and hemolysis (3); formation of ion channels in lipid bilayer membranes (19); antitumour activity against Ehrlich's ascites carcinoma cells (3); and inhibition of the cyclic adenosine 3,5monophosphate phosphodiesterase (11).

B. subtilis R14 strain has been investigated previously for agricultural application and has proven to be an effective biocontrol agent against important phytopathogens (13). In this paper the activity of surfactants produced by $B$. subtilis R14 against multidrug-resistant bacteria was investigated.

\section{MATERIALS AND METHODS}

\section{Microorganisms}

B. subtilis $\mathrm{R} 14$, isolated from the surface of kale leaves, was used in this work. The microorganism belongs to the Culture Collection of the Laboratory of Phytobacteriology of the Federal Rural University of Pernambuco (Brazil). From the lyophilized culture, subcultures were done on nutrient agar, consisted of meat extract $3.0 \mathrm{~g} / \mathrm{L}$, meat peptone $10.0 \mathrm{~g} / \mathrm{L}$ and agar $15.0 \mathrm{~g} / \mathrm{L}$.

Surfactant compounds were tested against a group of multiresistant bacteria isolated from clinical specimens: Pseudomonas aeruginosa (CI1, CI3, CI5, CI6, CI7, CI10, CI15); Escherichia coli CI18; Staphylococcus aureus (CI15, CI16, CI155, CI247, CI311, CI404) and Enteroccoccus faecalis (CI 55671, CI55918, CI144, CI068, CI56671, CI56354, CI55995, CI295, CI222, CI55195, CI56288) (Table 1). Four microorganisms from culture collections, representing each bacterial genus, were included in the study: Pseudomonas aeruginosa UFPEDA 39 and Staphylococcus aureus UFPEDA 22 (microorganisms belonging to the Culture Collection of the Antibiotic Departament of the Federal University of Pernambuco, Brazil), and Enterococcus faecalis ATCC 29212 and Escherichia coli ATCC 8739. The microorganisms were maintained on MuellerHinton agar slants at refrigerated temperature.

\section{Culture medium}

A defined medium described by Carvalho (4) was used for the production of surfactants and consisted of (per liter of distilled water): glucose, $40.0 \mathrm{~g} ;\left(\mathrm{NH}_{4}\right)_{2} \mathrm{SO}_{4}, 8.5 \mathrm{~g} ; \mathrm{NaNO}_{3}$, $8.5 \mathrm{~g} ; \mathrm{K}_{2} \mathrm{HPO}_{4}, 13.6 \mathrm{~g} ; \mathrm{KH}_{2} \mathrm{PO}_{4}, 4.0 \mathrm{~g} ; \mathrm{MgSO}_{4} .7 \mathrm{H}_{2} \mathrm{O}, 0.5 \mathrm{~g}$; and in this medium $10 \mathrm{~mL}$ of the solution consisting of (per liter of distilled water): $\mathrm{CaCl}_{2}, 0.42 \mathrm{~g} ; \mathrm{FeSO}_{4} \cdot 7 \mathrm{H}_{2} \mathrm{O}, 2.29 \mathrm{~g} ; \mathrm{MnCl}_{2} \cdot 4 \mathrm{H}_{2} \mathrm{O}$, $0.10 \mathrm{~g} ; \mathrm{ZnCl}_{2}, 0.17 \mathrm{~g} ; \mathrm{CuCl}_{2}, 0.03 \mathrm{~g} ; \mathrm{CoCl}_{2} \cdot 6 \mathrm{H}_{2} \mathrm{O}, 0.06 \mathrm{~g}$ and
$\mathrm{Na}_{2} \mathrm{MoO}_{4} \cdot 2 \mathrm{H}_{2} \mathrm{O}, 0.06 \mathrm{~g}$ was added. The broth $\mathrm{pH}$ was adjusted to 7 .

\section{Inoculum and culture conditions}

B. subtilis R14 was streaked on a nutrient agar slant and incubated at $37^{\circ} \mathrm{C}( \pm 0.5)$. After $24 \mathrm{~h}$, two loops of cells were inoculated in $25 \mathrm{~mL}$ of nutrient broth in a $250 \mathrm{~mL}$ Erlenmeyer flask and incubated in a rotatory shaker (New Brunswick Scientific, model C25KC) at $250 \mathrm{rpm}$ and $37^{\circ} \mathrm{C}( \pm 0.5)$ until absorbance around 3, measured spectrophotometrically at 600 $\mathrm{nm}$ (Hewlett Packard 8453) was reached. The culture from the Erlenmeyer flask was then transferred to $225 \mathrm{~mL}$ of production medium in a Fernbach flask and incubated in the rotatory shaker at $150 \mathrm{rpm}$ and $30^{\circ} \mathrm{C}( \pm 0.5)$ for $52 \mathrm{~h}$. Samples were collected at time-defined intervals and submitted to analysis for determination of biomass production, glucose consumption, nitrite production, and changes in surface tension, emulsification activity and biosurfactant concentration. All experiments were performed in triplicate.

\section{Analytical measurements}

Biomass concentration was determinated spectrophotometrically during the cultivation at $600 \mathrm{~nm}$ (Hewlett Packard 8453) and by determination of dry weight at $80^{\circ} \mathrm{C}$ for $24 \mathrm{~h}$ after filtration of the samples through $0.22 \mu \mathrm{m}$ membranes (4). With these results, a curve was plotted for the bacterial dry weight as a function of the optical density.

The concentration of glucose was assayed by the Trinder method, based on the enzymatic oxidation of glucose to gluconic acid and hydrogen peroxide (22).

Nitrite concentration was measured spectrophotometrically (Hewlett Packard 8453) at $543 \mathrm{~nm}$. This method was based on reduction of nitrate to nitrite, which reacts with sulfanilic acid and $\alpha$-naftilamine resulting in p-benzensulfonic-azo- $p-\alpha$ naftilamine. The product formed is directly proportional to the nitrite concentration in the sample $(8,12)$.

Culture samples were centrifuged at $11.000 \mathrm{xg}$ for 20 minutes for cell removal and the supernatant was submitted to surface tension measurement with a tensiometer (model KSV Sigma 70, $\mathrm{Hl}$, Finland) using Wilhelmy plate method. The emulsification activity was determined according to Cooper and Goldenberg (5): $1.5 \mathrm{~mL}$ of hexane was added to $1 \mathrm{~mL}$ of the supernatant in a screw cap tube and vortexed at high speed for 2 minutes. The emulsion stability was determined after $24 \mathrm{~h}$, and the emulsification index $\left(\mathrm{E}_{24}\right)$ was calculated by dividing the measured height of emulsion layer by the mixture's total height and multiplying by 100 .

\section{Precipitation and Extraction of Biosurfactant}

The surfactant was precipitated from cell-free broth of the culture of $52 \mathrm{~h}$ by adjusting the broth $\mathrm{pH}$ to 2.0 using $6 \mathrm{~N} \mathrm{HCl}$ and keeping it at $4^{\circ} \mathrm{C}$ overnight $(5,17)$. Precipitated material was 
Table 1. Susceptibility profile of the microorganisms used in the antimicrobial tests.

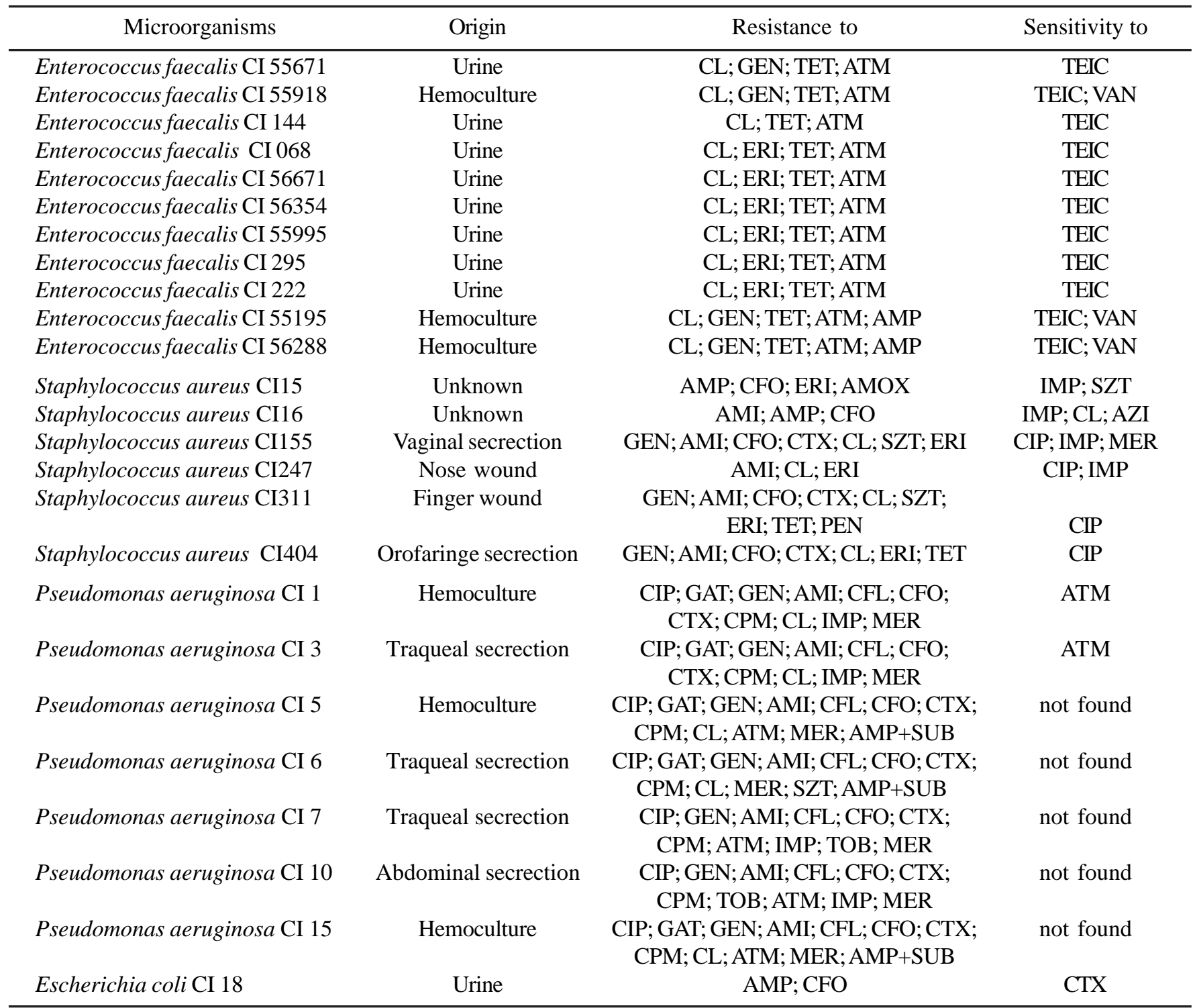

$\mathrm{AMI}=$ Amikacin $30 \mu \mathrm{g} ; \mathrm{AMP}=$ Ampicillin $10 \mu \mathrm{g}$; AMOX = Amoxicillin $10 \mu \mathrm{g} ; \mathrm{ATM}=$ Aztreonam $30 \mu \mathrm{g} ; \mathrm{AMP}+\mathrm{SUB}=\mathrm{Ampicillin}+\mathrm{Sulbactam}$ 10/10 $\mu \mathrm{g}$; AZI = Azithomycin $15 \mu \mathrm{g}$; CFO = Cefoxitin $30 \mu \mathrm{g}$; CFL = Cephalothin $30 \mu \mathrm{g}$; CIP = Ciprofloxacin $5 \mu \mathrm{g}$; CL = Chloramphenicol 30 $\mu \mathrm{g} ; \mathrm{CPM}=$ Cefepime $30 \mu \mathrm{g}$; CTX = Cefotaxime $30 \mu \mathrm{g}$; ERI = Erytromycin $15 \mu \mathrm{g}$; GEN = Gentamycin $10 \mu \mathrm{g}$; GAT = Gatifloxacin $10 \mu \mathrm{g}$; IPM $=$ Imipenem $10 \mu \mathrm{g}$, MER = Meropenem $10 \mu \mathrm{g}$; PEN = Penicillin G $10 \mathrm{IU}$; SZT = Sulfazotrim $25 \mu \mathrm{g}$; TET = Tetracycline $30 \mu \mathrm{g}$; TEIC = Teicoplanin $30 \mu \mathrm{g}$; TOB = Tobramycin $10 \mu \mathrm{g}$; VAN = Vancomycin $30 \mu \mathrm{g} ; \mathrm{CI}=$ Clinical Isolate.

colleted by centrifugation, $11.000 x \mathrm{xg}$ for $20 \mathrm{~min}$. The crude surfactant was lyophilized and weighed for quantification. For the extraction of biosurfactant compounds, $50 \mathrm{~mL}$ of chloroformmethanol $(2: 1 \mathrm{v} / \mathrm{v})$ was added to $500 \mathrm{mg}$ of the dry product and incubated in a rotatory shaker (New Brunswick Scientific, model $\mathrm{C} 25 \mathrm{KC})$ at $250 \mathrm{rpm}, 30^{\circ} \mathrm{C}( \pm 0.5)$ for 15 minutes. The mixture was filtrated using a $0.45 \mathrm{~mm}$ Millipore membrane (4). The filtrate
$(50 \mathrm{~mL})$ was used for thin layer chromatography (TLC) analysis and antimicrobial activity tests.

\section{Chemical characterization of biosurfactant}

The chemical characterization of the isolated compounds was done by TLC analysis. The components of the chloroform/ methanol extract were separated on silica gel $\left(\mathrm{Si} 60 \mathrm{~F}_{254}, 0.25\right.$ 
$\mathrm{mm}$, Merck) using chloroform-methanol-water (65:25:4v/v/v) as the solvent system. Spots were revealed by spraying with: a) distilled water and heating at $110^{\circ} \mathrm{C}$ for $5 \mathrm{~min}$, for detection of hydrophilic compounds; b) ninhydrin $0.05 \%$ w/v (in methanol/ water, $1: 1 \mathrm{v} / \mathrm{v}$ ) and heating at $100^{\circ} \mathrm{C}$ for $4-5 \mathrm{~min}$, for detection of compound with free amino groups; and c) rhodamine B $0.25 \% \mathrm{w} /$ $\mathrm{v}$ (in absolute ethanol) for detection of the presence of lipids under ultraviolet light (24). Surfactin (Sigma) was used as a standard.

The components of the chloroform/methanol extract were submitted to acid hydrolysis in $6 \mathrm{~N} \mathrm{HCl}$ at $105^{\circ} \mathrm{C}$ for $24 \mathrm{~h}$ for detection of free amino groups by ninhydrin $0.05 \% \mathrm{w} / \mathrm{v}$ by TLC (17).

Furthermore, the crude surfactant obtained was submitted to biochemical analysis of protein (9) and lipid (1) content.

\section{Antimicrobial activity}

The antimicrobial activity of the biosurfactant was evaluated using the agar diffusion method proposed by Bauer et al. (2). In order to produce an appropriate inoculum an overnight culture (grown at $37^{\circ} \mathrm{C} \pm 1.0$ ) of bacteria in Mueller-Hinton broth was standardized to an opacity equivalent to 0.5 on the McFarland scale $\left(10^{8} \mathrm{CFU} / \mathrm{mL}\right)$. The resulting suspension was diluted to yield a cellular concentration of $10^{7} \mathrm{CFU} / \mathrm{mL}$. Two $\mathrm{mL}$ of standardized suspensions of the microorganisms were deposited in Petri dishes (diameter $90 \mathrm{~mm}$ ) and $18 \mathrm{~mL}$ of Mueller-Hinton agar at $45^{\circ} \mathrm{C}$ was added. Aliquots of $20 \mathrm{~mL}$ of the filtrate were applied to paper disks ( $6 \mathrm{~mm}$ in diameter, Whatman $\left.\mathrm{N}^{\circ} 1\right)$, which resulted in disks containing $200 \mu \mathrm{g}$ of the product. After evaporation of the loading solvent, each disk was placed at the centre of the Petri dishes containing previously inoculated Mueller-Hinton medium and incubated at $37^{\circ} \mathrm{C}$ for $24 \mathrm{~h}$. At the end of the incubation time, the diameter of microbial growth inhibition halo was measured in millimeters using a ruler with a sliding caliper.

\section{RESULTS AND DISCUSSION}

\section{Biosurfactant Production}

The results of growth and biosurfactant production of $B$. subtilis R14 are presented in Fig. 1.

A direct relationship between microbial growth and biosurfactant production was observed, as had been previously observed for this strain (4) and B. subtilis C9 (15) in oxygen limited conditions. After 40 hours of cultivation, the complete consumption of glucose occurred coinciding with the maximum production of the biosurfactant. The maximum concentrations of biomass and crude biosurfactant obtained were $7.8 \mathrm{~g} / \mathrm{L}$ and $2.0 \mathrm{~g} / \mathrm{L}$, respectively (Fig. 1A).

Using the indirect method, it was shown that nitrate was reduced to nitrite. Davis et al. (6) demonstrated that in cultures under oxygen absence $B$. subtilis is capable of using nitrate as
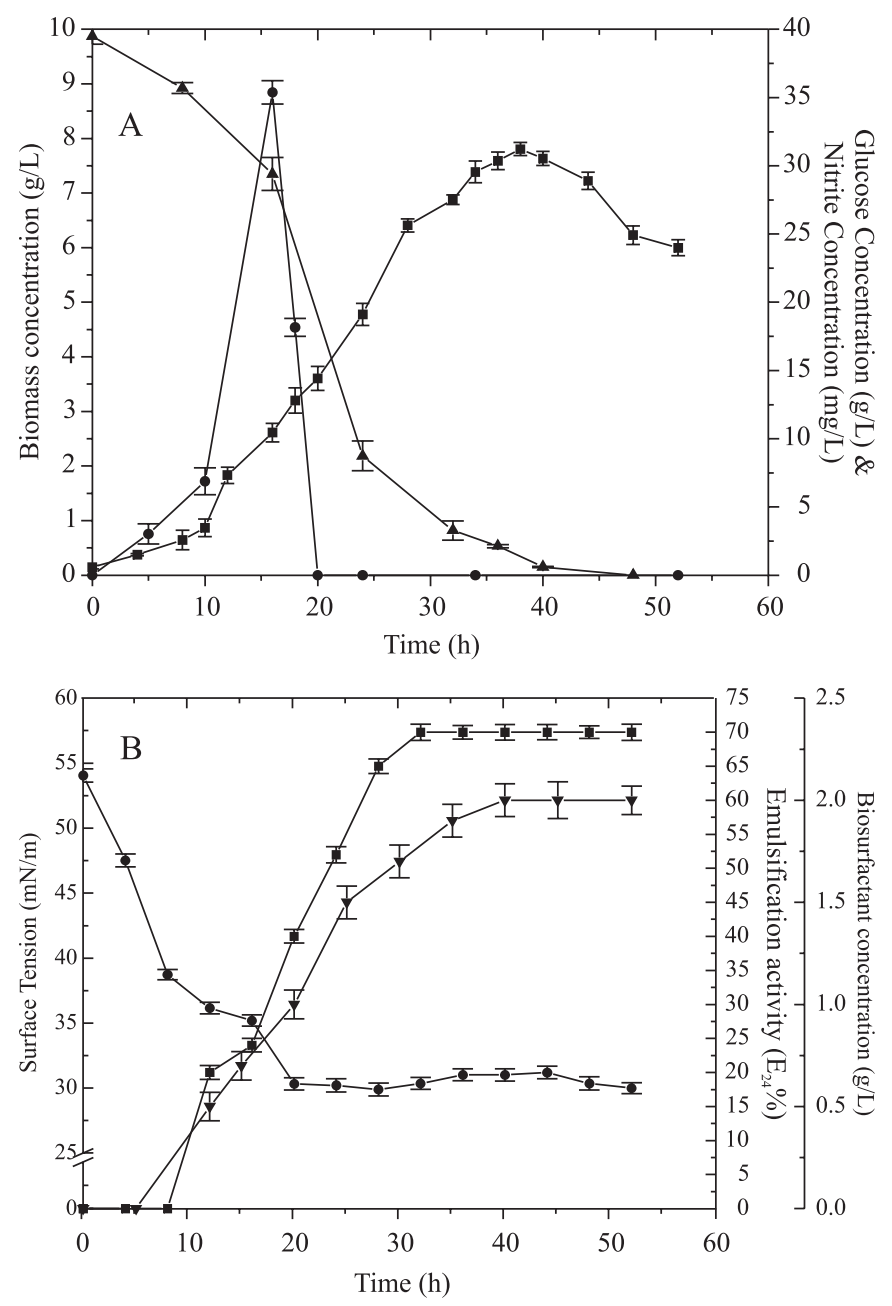

Figure 1. Growth and biosurfactant production by Bacillus subtilis R14. (A)- Biomass concentration ( $\mathbf{\square})$, nitrite concentration $(\mathbf{O})$, glucose concentration $(\mathbf{A})(\mathbf{B})$ - biosurfactant concentration $(\boldsymbol{\nabla})$, surface tension $(\mathrm{O})$ and emulsification activity $(\square)$ were monitored along the microbial growth.

a terminal electron acceptor. A rapid increase in nitrite concentration was observed between 5 and $16 \mathrm{~h}$, reaching the maximum concentration of $35.38 \mathrm{mg} / \mathrm{L}$ after $16 \mathrm{~h}$, suggesting that a restriction of oxygen throughout the culture of $B$. subtilis R14 had occurred.

The surface tension of the culture medium was reduced from $54 \mathrm{mN} / \mathrm{m}$ at the beginning of growth to $30 \mathrm{mN} / \mathrm{m}$ after 20 hours of cultivation (Fig. 1B). According to Mulligan (14), a good biosurfactant must reduce the surface tension of the water from 72 to $35 \mathrm{mN} / \mathrm{m}$, characterizing the product as a powerful surface-active agent.

The highest emulsification activity was $70 \%$, and was reached after 32 hours of cultivation. 


\section{Characterization of the Compounds}

Thin-layer chromatography revealed two white spots when the plate was sprayed with water, with $R_{\mathrm{f}}$ values 0.55 and 0.37 . The standard surfactin presented a retention index of 0.55 . The same spots were revealed with rhodamine B, indicating the presence of lipids in the compounds. No spot was revealed when the plate was sprayed with ninhydrin. However, when the biosurfactant was submited to hydrolisis, a spot could be observed when ninhydrin was used, indicating the presence of peptides, but the absence of free amino groups in the molecule. Similar results were observed by Yu et al. (24).

The biochemical analysis of the crude surfactant extract showed a lipid content of $49.4 \%$ and a protein content of $35.9 \%$, confirming that the surfactant had a lipopeptidic composition, similar to results reported by Nitschke and Pastore (16) for another strain of $B$. subtilis.

\section{Antimicrobial Activity}

The results of the antimicrobial activity of the lipopeptides produced by $B$. subtilis R14 against pathogenic bacteria are shown in Table 2.

The compounds showed higher activity against Grampositive cocci than against Gram-negative bacilli. For Enterococcus faecalis, the halos presented a mean value of $14.6 \mathrm{~mm}$. These results are important since these microorganisms have natural resistance to aztreonam, co-trimoxazole, cephalosporins, chloramphenicol and clindamycin and low sensibility to aminoglycosides and penicillin $\mathrm{G}$ as discussed by Tavares (21) and Furtado (7).

The halos indicating the antimicrobial activity of the compounds against Staphylococcus aureus presented a mean value of $14.2 \mathrm{~mm}$. The $S$. aureus 311 isolate was the most sensitive, Staphylococcus with a halo diameter of $28.1 \mathrm{~mm}$. It is important to note that some of these strains are resistant to at least two $\beta$-lactams.

For Escherichia coli the mean halo diameter was $13.8 \mathrm{~mm}$ and for Pseudomonas aeruginosa the diameter varied from 9.8 to $12.1 \mathrm{~mm}$.

The activity against Gram-negative bacteria was lower when compared to Gram-positive bacteria. Singh and Cameotra (20) have also observed that lipopeptide N1, produced by $B$. subtilis $\mathrm{C} 1$, was active against several microorganisms, especially $S$. aureus and Mycobacterium sp.

The lipopeptide surfactants produced by Bacillus genus present a great potential for biotechnological and biopharmaceutical applications due their biological properties. Future work should be done in order to investigate the chemical structure and cellular toxicity of these compounds.

\section{ACKNOWLEDGEMENTS}

The authors are grateful to UFPE (Universidade Federal de Pernambuco) for the financial support.
Table 2. Antimicrobial activity of biosurfactant produced by $B$. subtilis R14.

\begin{tabular}{|c|c|c|}
\hline & Microorganisms & $\begin{array}{c}\operatorname{Halo}(\mathrm{mm}) \\
\chi \pm \delta\end{array}$ \\
\hline 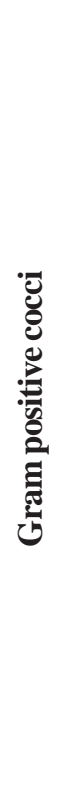 & $\begin{array}{l}\text { Enterococcus faecalis CI } 55671 \\
\text { Enterococcus faecalis CI } 55918 \\
\text { Enterococcus faecalis CI } 144 \\
\text { Enterococcus faecalis CI } 068 \\
\text { Enterococcus faecalis CI } 56671 \\
\text { Enterococcus faecalis CI } 56354 \\
\text { Enterococcus faecalis CI } 55995 \\
\text { Enterococcus faecalis CI } 295591- \\
\text { Enterococcus faecalis CI } 222 \\
\text { Enterococcus faecalis CI } 55195 \\
\text { Enterococcus faecalis CI } 56288 \\
\text { Enterococcus faecalis ATCC } 29212 \\
\text { Staphylococcus aureus CI155 } \\
\text { Staphylococcus aureus CI311 } \\
\text { Staphylococcus aureus CI15 } \\
\text { Staphylococcus aureus CI404 } \\
\text { Staphylococcus aureus CI247 } \\
\text { Staphylococcus aureus CI16 } \\
\text { Staphylococcus aureus UFPEDA22 }\end{array}$ & $\begin{array}{l}12.1 \pm 0.2 \\
15.9 \pm 0.1 \\
13.8 \pm 0.1 \\
17.4 \pm 0.1 \\
13.2 \pm 0.2 \\
12.4 \pm 0.2 \\
14.7 \pm 0.1 \\
15.3 \pm 0.1 \\
16.2 \pm 0.2 \\
16.7 \pm 0.2 \\
12.5 \pm 0.1 \\
15.9 \pm 0.1 \\
13.7 \pm 0.2 \\
28.1 \pm 0.1 \\
12.9 \pm 0.1 \\
10.7 \pm 0.1 \\
10.4 \pm 0.1 \\
10.7 \pm 0.1 \\
13.2 \pm 0.2\end{array}$ \\
\hline \multirow[t]{2}{*}{ 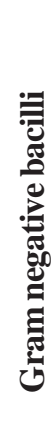 } & $\begin{array}{l}\text { Pseudomonas aeruginosa } \text { CI } 1 \\
\text { Pseudomonas aeruginosa } \text { CI } 3 \\
\text { Pseudomonas aeruginosa } \text { CI } 5 \\
\text { Pseudomonas aeruginosa } \text { CI } 6 \\
\text { Pseudomonas aeruginosa } \text { CI } 7 \\
\text { Pseudomonas aeruginosa } \text { CI } 10 \\
\text { Pseudomonas aeruginosa } \text { CI } 15 \\
\text { Pseudomonas aeruginosa } \text { UFPEDA } 39\end{array}$ & $\begin{array}{l}10.7 \pm 0.1 \\
12.1 \pm 0.1 \\
09.8 \pm 0.1 \\
10.5 \pm 0.1 \\
10.5 \pm 0.1 \\
11.3 \pm 0.2 \\
10.4 \pm 0.2 \\
10.3 \pm 0.1\end{array}$ \\
\hline & $\begin{array}{l}\text { Escherichia coli } \text { CI } 18 \\
\text { Escherichia coli ATCC } 8739\end{array}$ & $\begin{array}{l}14.4 \pm 0.1 \\
13.2 \pm 0.2\end{array}$ \\
\hline
\end{tabular}

ATCC-American Type Culture Collection; UFPEDA- Universidade Federal de Pernambuco - Departamento de Antibióticos; CI- Clinical Isolate; $\boldsymbol{\chi} \pm \boldsymbol{\delta}$ Mean \pm Standard Deviation.

\section{RESUMO}

\section{Atividade antimicrobiana de surfactantes produzidos por Bacillus subtilis $\mathbf{R} 14$ frente a bacterias multidroga-resistentes}

Os lipopeptídeos representam uma classe de surfactantes microbiológicos com crescente interesse científico, terapêutico e biotecnológico. O gênero Bacillus é um dos maiores produtores destes compostos ativos. Dentre as espécies produtoras de biossurfactante, $B$. subtilis produz surfactina um dos mais conhecidos. Estes compostos atuam como 
antibióticos, antivirais, agente antitumorais, imunomoduladores e inibidores enzimáticos. O objetivo deste trabalho foi determinar a atividade antimicrobiana de biossurfactantes, obtidos pelo cultivo de B. subtilis R14, frente a bactérias multidrogaresistentes. Durante o cultivo em meio quimicamente definido, a tensão superficial do meio foi reduzida de $54 \mathrm{mN} / \mathrm{m}$ no início do crescimento microbiano para $30 \mathrm{mN} / \mathrm{m}$ depois de $20 \mathrm{~h}$. Uma concentração de surfactante bruto de $2 \mathrm{~g} / \mathrm{L}$ foi obtida depois de $40 \mathrm{~h}$ de cultivo. Uma caracterização preliminar sugeriu que dois surfactantes foram produzidos. A avaliação antimicrobiana destes compostos foi realizada frente a vinte e nove bactérias. O perfil de multidroga-resistência foi previamente definido para Enterococcus faecalis (11 cepas) Staphylococcus aureus (6 cepas), Pseudomonas aeruginosa (7 cepas) e Escherichia coli IC18. Todas as cepas foram sensíveis aos surfactantes, em particular Enterococcus faecalis. Os resultados demonstraram que os lipopeptídios têm um amplo espectro de ação, incluindo microrganismos multidroga-resistentes.

Palavras-chave: Biossurfactante, Bacillus subtilis, Lipopeptídios, Atividade antimicrobiana

\section{REFERENCES}

1. Bligh, E.C.; Dyer, W.J. (1959). A rapid method of total lipid extraction and purification. Can. J. Biochem. Physiol., 37, 911-917.

2. Bauer, A.W.; Kirby, W.M.M.; Sherris, J.C.; Ture, K.M. (1966). Antibiotic susceptibility testing a standardized single disk method. Am. J. Clin. Path., 45, 493-496.

3. Cameotra, S.S.; Makkar, R.S. (2004). Recent applications of biosurfactant as biological and immunological molecules. Curr Opin Microbiol., 7, 262-266.

4. Carvalho, A.L.V. (2005). Fisiologia de Bacillus subtilis R14: Produção de lipopeptídeos e esporos. Recife, Brasil, 50p.( MSc. Dissertação. Pós Biotec. UFPE.).

5. Cooper, D.G.; Goldenberg, B.G. (1987). Surface-active agents from two Bacillus species. Appl. Environ. Microbiol., 53, 224-229.

6. Davis, D.A.; Lynch, H.C.; Varley, J. (1999) The production of surfactin in batch culture by Bacillus subtilis ATCC 21332 is strongly influenced by the conditions of nitrogen metabolism. Enz. Microbiol. Technol., 25, 322-329.
7. Furtado, G.H.C.; Martins, S.T.; Coutinho, A.P.; Soares, G.M.M.; Wey, S.B.; Medeiros, E.A.S. (2005). Rev. Saúde Pública, 39, 41-46.

8. Gerhardt, C.T.; Murray R.G.E.; Wood, W.A.; Krieg, N.R. (1986). Methods for general and molecular Bacteriology. ASM Press, Washington, D.C.

9. Gornall, A.G.; Bardawill, C.S.; David, M.M. (1949). Determination of serum protein by means of the biuret reaction. J. Biol. Chem. 177, 751-756.

10. Greek, B.F. (1991) Sales of detergents growing despite recession. Chem. Eng. News, 69, 25-52.

11. Hosono, K.; Suzuki, H. (1983). Acylpeptides, the inhibitors of cyclic adenosine 3',5'-monophosphodiesterase. III. Inhibition of cyclic AMP phosphodiesterase. J. Antibiot. Japan, 36, 679-683.

12. Master, R.N. (1996). Nitrate reduction. In: Isenberg, H.D. (ed): Clinical Microbiology Procedure Handbook. ASM Press, Washington, D.C.

13. Monteiro, L.; Mariano, R.L.R.; Souto-Maior, A.M. (2005). Antagonism of Bacillus spp. against Xantomonas campestris pv. Campestris. Braz. Arch. Biol. Techn., 48, 23-29.

14. Mulligan, C.N. (2004). Environmental applications for biosurfactants. Environ. Poll., 7, 362-366.

15. Nitschke, M.; Pastore, G.M. (2002). Biossurfactantes: propriedades e aplicações. Química Nova 25, 772-776.

16. Nitschke, M.; Pastore, G.M. (2006). Production and properties of a surfactant obtained from Bacillus subtilis grown on cassava wastewater Biores. Technol., 97, 336-341.

17. Peypoux, F.; Bonmatin, J.M.; Wallach, J. (1999). Recent trends in the biochemistry of surfactin. Appl. Microbiol. Biotechnol., 51, 553-563.

18. Rosenberg, E.; Ron, E.Z. (1999). High and low-molecular-mass microbial surfactants. Appl. Microbiol. Biotechnol., 52, 154-162.

19. Sheppard, J.D.; Jumarie, C.; Cooper, D.G. (1997). Ionic channels induced by surfactin in planar lipid bilayer membranes. Biochim. Biophys. Acta, 1064, 44-49.

20. Singh, P.; Cameotra, S.S. (2004). Potential applications of microbial surfactants in biomedical sciences. Trends in Biotech., 22, 142-146.

21. Tavares, W. (2000). Bactérias Gram-positivas problemas: resistência do estafilococo, do enterococo e do pneumococo aos antimicrobianos. Rev. Soc. Bras. Med. Trop., 33, 281-301.

22. Trinder, D. (1969). Determination of glucose in blood using glucose oxidase with an alternative oxygen acceptor. Ann. Clin. Biochem., 6, 24-27.

23. Vater, J. (1986). Lipopeptides, an attractive class of microbial surfactants. Prog. Coll. Pol. Sci. S., 72, 12-18.

24. Yu, G.Y.; Sinclair, J.B.; Hartman, G.L.; Bertagnolli, B.L. (2002). Production of iturin A by Bacillus amyloliquefaciens suppressing Rhizoctonia solani. Soil Biol. Biochem., 34, 955-963. 